\title{
Francis Jones, M.Sc.
}

Francis Jones was a pioneer. He was the last to survive of the small band of chemists who introduced into our public schools the teaching of Natural Science. It is fortunate that he had the temperament of a successful schoolmaster and unusual tact and patience. If he had lacked these qualities, the experiment of the Manchester Grammar School might well have been a failure, and it is impossible to estimate what would have been the results of such a disaster. As it was, the success of the undertaking did not encourage rapid imitation.

Jones, unhampered by tradition, was free to work out his own methods of teaching. It is not surprising, therefore, that in the laboratory he followed closely the models of his teacher Bunsen of Heidelberg, by whom so many of the English chemists of his period were trained, and Jones's pupils who are now in charge of laboratories of their own are still teaching to their students the beautiful dry tests of Bunsen, in defiance of fashion and examining boards. Have not the blowpipe and the test-tube been too hastily discredited? When his pupils came to do quantitative experiments they were allowed to use genuine chemical balances which they were taught to handle properly. Experiments which needed for their successful performance real manipulative skill were included in the course. He wrote a textbook of practical chemistry which was for many years a standard work and has been translated into several languages.

Jones started his work at the Manchester Grammar School in 1872, during the period of great scientific awakening when popular science lectures attracted large audiences in the chief industrial centres. Nevertheless, science was considered to be rather vulgar by many of the educated classes. It was fourteen years later that the writer, in opposition to the wishes of the High Master, entered the Science V, the refuge of the incorrigibly stupid. The High Master in giving his consent uttered the warning that his (the writer's) chance of becoming a well-educated man would thereby be lost.

Francis Jones's most important contribution to pure science was the discovery of the method of preparation of the hydrides of boron. These gases have been recently separated by fractional distillation at low temperature and have been shown to be compounds of peculiar interest. The rest of his original work is mainly analytical in character. 
The share which he took in the administrative work of the school and of the scientific community of Manchester was considerable. An active member of the Manchester Literary and Philosophical Society, he served as Secretary for some years, and was President from 1909-11. He was a senior Fellow of the Royal Society of Edinburgh and of the Chemical Society of London.

He was admired and respected by his colleagues, and revered by his pupils, with many of whom he became an intimate friend after they had left the school.

He died on 22nd October 1925, aged 80 , of bronchitis and heart weakness. His memory will always be treasured by many.

D. L. C. 